\title{
Dynamic Performance of a Solar Hybrid Heating Network Integrated with a Micro- Cogeneration Unit Serving a Small-Scale Residential District including Electric Vehicles
}

\author{
Antonio Rosato, Antonio Ciervo, Giovanni Ciampi, Michelangelo Scorpio, \\ Francesco Guarino, Sergio Sibilio \\ University of Campania Luigi Vanvitelli, Department of Architecture and Industrial Design, \\ Aversa, Italy
}

\begin{abstract}
A solar hybrid district heating network integrated with a seasonal borehole thermal energy storage is modelled, simulated and analyzed over a 5-year period. The system is devoted to satisfying the thermal demand of a smallscale district consisting of 6 typical Italian single-family houses in Naples (south of Italy); the charging of 6 plugin electric vehicles is also considered. The performance of the proposed plant is investigated by considering two alternative natural gas-fueled back-up systems. The energy, environmental and economic performance of the proposed plant are analyzed and compared with those associated to a conventional heating system in order to assess the potential benefits.
\end{abstract}

\section{Introduction}

Solar energy is considered one of the most promising options for energy saving and reduction of harmful emissions. Seasonal thermal energy storage allows for thermal energy storage over weeks and months, with it being a challenging key technology for solving the timediscrepancy between solar energy supply and thermal energy demand; borehole thermal energy storage (BTES) has the most favorable condition for long-term energy storage (Rad and Fung, 2016; Ciampi et al., 2018). However, the utilization of intermittent energy sources characterized by a stochastic behavior requires other generation units to compensate the lack of energy. District heating $(\mathrm{DH})$ networks based on solar energy are gaining more and more interest in the scientific community. Several technologies can be integrated into solar DH systems; in particular, micro-cogeneration (MCHP) systems, i.e. devices characterized by the combined production of electric and thermal energy from a single fuel source with an electric output lower than $50 \mathrm{~kW}_{\mathrm{el}}$, are considered by the European Community as one of the most effective measures to save primary energy and reduce greenhouse gas emissions in small-scale applications (Rosato et al., 2017; Sibilio and Rosato, 2015; Directive 2012/27/EU; Mura et al., 2015; Mura et al., 2015). The diffusion of electric vehicles (EVs) could help in (i) reducing the large energy consumption of the transport sector and related greenhouse gases emissions, (ii) improving the local air quality in urban areas thanks to the reduced emission of local pollutants, as well as (iii) lowering the costs per kilometer for the end-users when compared to internal combustion engine vehicles
(Angrisani et al., 2014). The micro-cogeneration devices applied in residential units generally operate under a heatload following control strategy in response to variations in heat demand (Sibilio and Rosato, 2015); in this case, a large fraction of the cogenerated electricity is usually produced at times when the electric demand of the building is lower than MCHP electric output due to the usual mismatch between electric and thermal demands (Ribberink and Entchev, 2014), requiring substantial amounts of electricity to be exported to the grid with low revenues. EVs consume considerable amounts of electricity; they are mostly driven during the day and charged at home during the night, so that the recharging of EVs could be a way to increase the own use of cogenerated electricity, enhancing the profitability of MCHP devices. Few papers are available in literature focusing on small-scale solar hybrid DH systems. Buoro et al. (2014) investigated the integration between distributed energy supply system, solar thermal plant and heat storage for a district composed of 9 industrial facilities located in the north-east of Italy. The work of Kallert et al. (2017) focused on the analysis of a low temperature DH network serving a small group of 10 low energy residences. Marguerite et al. (2017) presented the results of a multi-criteria evaluation of different design scenarios for a micro-DH network in Vienna (Austria) serving two office buildings. To the knowledge of the authors, the potential of the joint use of solar DH networks and micro-cogeneration units under the climatic conditions of Italy has not been investigated with reference to small-scale applications. The literature review also revealed that possible synergy between micro-cogeneration and EV charging has been poorly analyzed (Ribberink and Entchev, 2014; Angrisani et al., 2015).

In this paper a small-scale DH network based on a field of solar collectors and integrated with a seasonal borehole thermal energy storage is modelled, simulated and analyzed over a 5-year period by means of the TRaNsient SYStems software platform (TRNSYS). The system is devoted to satisfying the heating demand of a district consisting of 6 typical Italian single-family houses under the climatic conditions of Naples (south of Italy). The district also includes a set of 6 plug-in EVs characterized by different charging profiles representing scenarios in which EVs would drive two different daily distances (30 and $53 \mathrm{~km}$ ) and would be charged at three different power levels $\left(2.2,3.6\right.$ and $\left.6.6 \mathrm{~kW}_{\mathrm{el}}\right)$; the charging profiles have 
been identified by means of the Plug-in Electric Vehicle and Charge Impact Model developed by the Natural Resources Canada. The performance of the proposed plant is investigated by considering two alternative backup systems in order to compensate the intermittency of solar source: 1) a conventional $26.6 \mathrm{~kW}_{\text {th }}$ natural gas-fired boiler (VAILLANT), and 2) a $28.0 \mathrm{~kW}_{\text {th }}$ natural gasfueled internal combustion engine-based microcogeneration unit (COGENGREEN). The primary energy consumption, the equivalent carbon dioxide emissions and the operating costs of the proposed district network are evaluated based on the simulation results and compared with those associated to a conventional decentralized heating system assumed as reference with the main aims of assessing (i) the feasibility of microcogeneration units integrated into DH systems, (ii) the impact of EVs charging on MCHP profitability, as well as (iii) the overall potential energy, environmental and economic benefits of small-scale solar DH applications integrating seasonal thermal energy storages.

\section{Description of the district}

The district served by the proposed plant is composed of 6 typical Italian single-family residences located in Naples (latitude $=40^{\circ} 51^{\prime} 46^{\prime \prime} 80 \mathrm{~N}$; longitude $=14^{\circ} 16^{\prime} 36^{\prime}$ " 12 E; Heating Degree Days=1,034). 3 different typologies of residential buildings have been considered (A, B, C). In particular, the district is composed of 2 buildings for each typology; each building typology differs from the others in terms of floor area, windows' area, volume, maximum simultaneous occupants, heat (heating and domestic hot water) and electricity demands, as indicated in Table 1.

Table 1: Description of building's typologies.

\begin{tabular}{|c|c|c|c|}
\cline { 2 - 4 } \multicolumn{1}{c|}{} & $\begin{array}{c}\text { Typology } \\
\text { A }\end{array}$ & $\begin{array}{c}\text { Typology } \\
\text { B }\end{array}$ & $\begin{array}{c}\text { Typology } \\
\text { C }\end{array}$ \\
\hline $\begin{array}{c}\text { Number of } \\
\text { buildings (-) }\end{array}$ & 2 & 2 & 2 \\
\hline $\begin{array}{c}\text { Floor/windows area } \\
\left(\mathrm{m}^{2}\right)\end{array}$ & $60 / 84$ & $78 / 102$ & $114 / 230$ \\
\hline Volume (m $\left.{ }^{3}\right)$ & 230 & 370 & 448 \\
\hline $\begin{array}{c}\text { Maximum } \\
\text { simultaneous } \\
\text { occupants (-) }\end{array}$ & 3 & 4 & 5 \\
\hline $\begin{array}{c}\text { Annual } \\
\text { heat/electricity } \\
\text { demand (kWh) }\end{array}$ & $2808.6 /$ & $3308.8 /$ & $5174.4 /$ \\
\hline $\begin{array}{c}\text { Maximum daily } \\
\text { heat/electricity } \\
\text { demand (kWh) }\end{array}$ & $43.7 / 11.6$ & $52.9 / 12.9$ & $62.8 / 13.8$ \\
\hline
\end{tabular}

For each building typology, a specific annual stochastic profile (composed of 365 different daily stochastic profiles) with a one-minute time resolution has been considered for modeling both the occupancy profiles as well as the electric demand profiles (related to lighting and domestic appliances); these annual stochastic profiles have been obtained based on the models developed by Richardson et al. (2010). The annual internal gain profiles for each building typology have been derived from the above-mentioned profiles by assuming a heat gain of 70 /occupant, a heat gain of lighting systems equal to $70 \%$ of nominal electric power as well as a heat gain for each domestic appliance based on manufacturer data. In order to be compliant with Italian legislation requirements (DM 26/06/2015), the thermal transmittance of the buildings envelopes has been equated to the given threshold values $\left(2.40 \mathrm{~W} / \mathrm{m}^{2} \mathrm{~K}\right.$ for windows, $0.36 \mathrm{~W} / \mathrm{m}^{2} \mathrm{~K}$ for roofs, 0.40 $\mathrm{W} / \mathrm{m}^{2} \mathrm{~K}$ for floors, $0.38 \mathrm{~W} / \mathrm{m}^{2} \mathrm{~K}$ for external vertical walls), whatever the building typology is. The European Standard EN 12831 has been used to calculate the air exchange rate (assumed equal to 0.24 volumes per hour for each building typology), i.e. the number of interior volume air changes that occur per hour, induced by the wind and stack effect on the building envelope. Several sets of yearly load profiles for the domestic hot water (DHW) demand have been specified within the IEA-SHC Task 26 (Jordan and Vajen, 2001); each profile consists of a value of water flow rate for every time step, with the values and the time of occurrence of every incidence have been selected by statistical means. In this study, a demand profile with an average basic load of 100 1/day in the time scale of 1 minute has been used for both building typologies $\mathrm{A}$ and $\mathrm{B}$, while a demand profile with an average basic load of $2001 /$ day in the time scale of 1 minute has used for building typology $\mathrm{C}$.

\section{Description of the proposed plant}

The schematic of the proposed Central Solar Heating Plant with Seasonal Storage (CSHPSS) is reported in Figure 1. In this figure, the following main components can be identified: end-users (6 residential buildings), solar collectors field (SF), heat dissipator (HD), short-term thermal energy storage (STTES), borehole thermal energy storage (BTES) with vertical double U-pipes borehole heat exchangers, back-up system (BS), 2 heat exchangers (HE1 and HE2), 6 electric vehicles (EVs), local individual boilers (B) for DHW production, fan-coils (FC), pumps (P), 3-way valves and pipes. The solar energy captured by the solar thermal collectors is first transferred, through the heat exchanger HE1, into the short-term thermal energy storage; dissipation of solar thermal energy surplus is obtained by blowing air across a finned coil heat exchanger when the solar collectors outlet temperature is higher than $95^{\circ} \mathrm{C}$. From the STTES, if there is a heating demand, the solar energy is transferred through the heat exchanger HE2 into the distribution network, and then to the end-users for space heating (each building is equipped with a group of fan-coils). If the solar energy is not immediately required for heating purposes, it can be moved from the STTES to the BTES during the whole year ("BTES charging mode"). Only during the heating season, thermal energy stored in the BTES field can return into the STTES ("BTES discharging mode") to integrate the temperature level. During the charging phase, the flow direction is from the center to the boundaries of the BTES to obtain high temperatures in the center and lower ones at the boundaries of the storage; the flow direction is reversed during the discharging phase. 


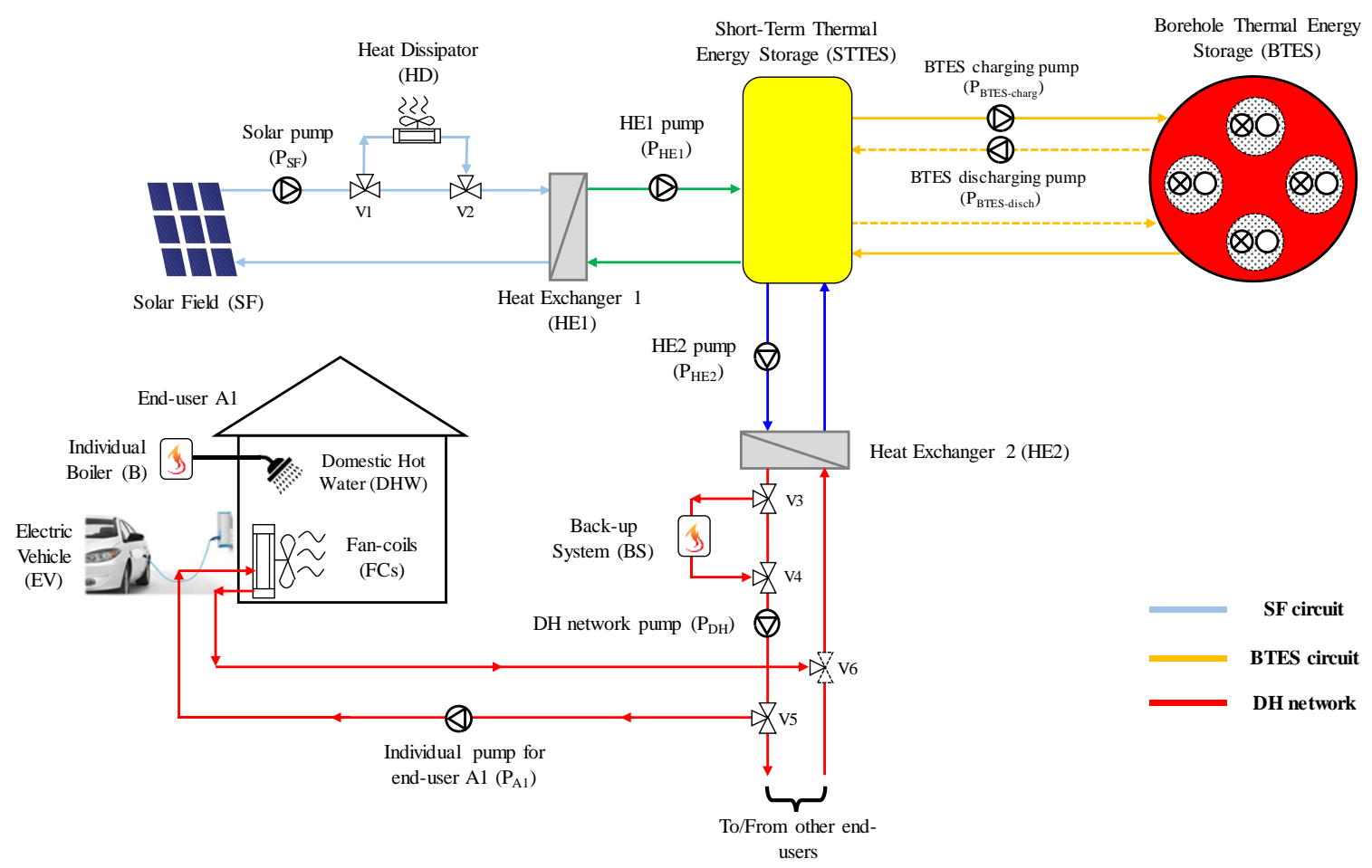

Figure 1: Schematic of the proposed central solar heating plant.

In order to supplement the space heating demand when the solar energy recovered and stored in the short- and long-term storages cannot meet the energy requirements, a back-up system is used. In particular, the following two alternative cases involving different technologies have been considered:

case 1) $26.6 \mathrm{~kW}_{\text {th }}$ Main natural gas-fired Boiler (MB) (VAILLANT);

case 2) $28.0 \mathrm{~kW}_{\text {th }}$ natural gas-fueled internal combustion engine-based micro-cogeneration unit (with a nominal electric output of $\left.12.0 \quad \mathrm{~kW}_{\mathrm{el}}\right)$ (COGENGREEN).

Table 2 summarizes the main characteristics of the leading components. The total aperture area of solar collectors $\left(55.44 \mathrm{~m}^{2}\right)$, the volume of the STTES $\left(6.0 \mathrm{~m}^{3}\right)$, the volume of the BTES $\left(435.8 \mathrm{~m}^{3}\right)$ as well as the number (8) and depth $(12.43 \mathrm{~m})$ of the boreholes have been determined by the authors based on the simulation results of a huge sensitivity analysis performed in a previous study (Ciampi et al., 2018).

Natural Resources Canada has developed a Plug-in Electric Vehicle and Charge Impact Model (Natural Resources Canada); it is a versatile software tool that is used to determine the impact of EV charging on the future electricity grid, fuel costs and emissions. It is used in this paper to create a set of $6 \mathrm{EV}$ weekly charging profiles (named EV1, EV2, EV3, EV4, EV5 and EV6) representing scenarios based up actually driving data in which EVs would drive two different daily distances (30 and $53 \mathrm{~km}$ ) and would be charged at three different power levels $\left(2.2,3.6\right.$ and $\left.6.6 \mathrm{~kW}_{\mathrm{el}}\right)$. In this paper the proposed CSHPSS has been analyzed with and without considering a set of 6 plug-in EVs (one EV per each single builing) characterized by the charging profiles indicated in Figures 2. Specifically, Figure 2 a refers to profiles with a daily driving distance of $30 \mathrm{~km}$ and Figure $2 \mathrm{~b}$ refers to profiles with $53 \mathrm{~km}$ as daily driving distance.

Table 2: Main characteristics of plant components.

\begin{tabular}{|c|c|}
\hline \multicolumn{2}{|c|}{ Solar thermal collectors (Kloben) } \\
\hline Collector technology / model & $\begin{array}{c}\text { Flat plate / } \\
\text { FSK } 2.5\end{array}$ \\
\hline Apertura area of a single collector $\left(\mathrm{m}^{2}\right)$ & 2.31 \\
\hline Number of collectors & 24 (8 rows) \\
\hline Tilted angle / Azimuth / Orientation & $30^{\circ} / 0^{\circ} /$ South \\
\hline \multicolumn{2}{|c|}{ Short-Term Thermal Energy Storage (PARADIGMA) } \\
\hline Typology & $\begin{array}{c}\text { Vertical } \\
\text { cylindrical tank }\end{array}$ \\
\hline Volume $\left(\mathrm{m}^{3}\right) /$ Height $(\mathrm{m})$ & $6.0 / 3.5$ \\
\hline \multicolumn{2}{|c|}{ Boreholes Thermal Energy Storage } \\
\hline Volume $\left(\mathrm{m}^{3}\right)$ & 435.8 \\
\hline Borehole radius $(\mathrm{m})$ & 0.15 \\
\hline Number (-) / Depth of boreholes (m) & $8 / 12.43$ \\
\hline Thermal conductivity of soil (W/mK) & 3.0 \\
\hline Thermal conductivity of grout (W/mK) & 5.0 \\
\hline Center-to-center half distance (m) & 0.05 \\
\hline U-pipe spacing / borehole spacing (m) & $0.0254 / 2.25$ \\
\hline Inner/outer radius of U-pipe $(\mathrm{m})$ & $0.01372 / 0.01669$ \\
\hline Pipe / Gap thermal conductivity (W/mK) & $0.42 / 1.40$ \\
\hline Maximum storage temperature $\left({ }^{\circ} \mathrm{C}\right)$ & 90 \\
\hline \multicolumn{2}{|c|}{ Main Boiler (VAILLANT) } \\
\hline Fuel / Rated capacity (kW) & Natural gas / 26.6 \\
\hline Minimum turn-down ratio (-) & 0.4 \\
\hline \multicolumn{2}{|c|}{ MCHP unit (COGENGREEN) } \\
\hline $\begin{array}{c}\text { Fuel } \\
\end{array}$ & Natural gas \\
\hline Rated electric / thermal output $(\mathrm{kW})$ & $12.0 / 28.0$ \\
\hline Rated electric / thermal efficiency (\%) & $27.9 / 65.1$ \\
\hline
\end{tabular}


The electric requirements (due to domestic appliances, lighting systems, pumps, fan-coils, EVs, etc.) are satisfied with the electric energy supplied by the central grid for the configuration with the Main Boiler as back-up system; in the case of the MCHP unit is adopted as back-up system, the cogenerated electricity is used directly in order to cover the electric demand; any unused excess electricity is sent to the power line, with the electric grid covering the peak demands.
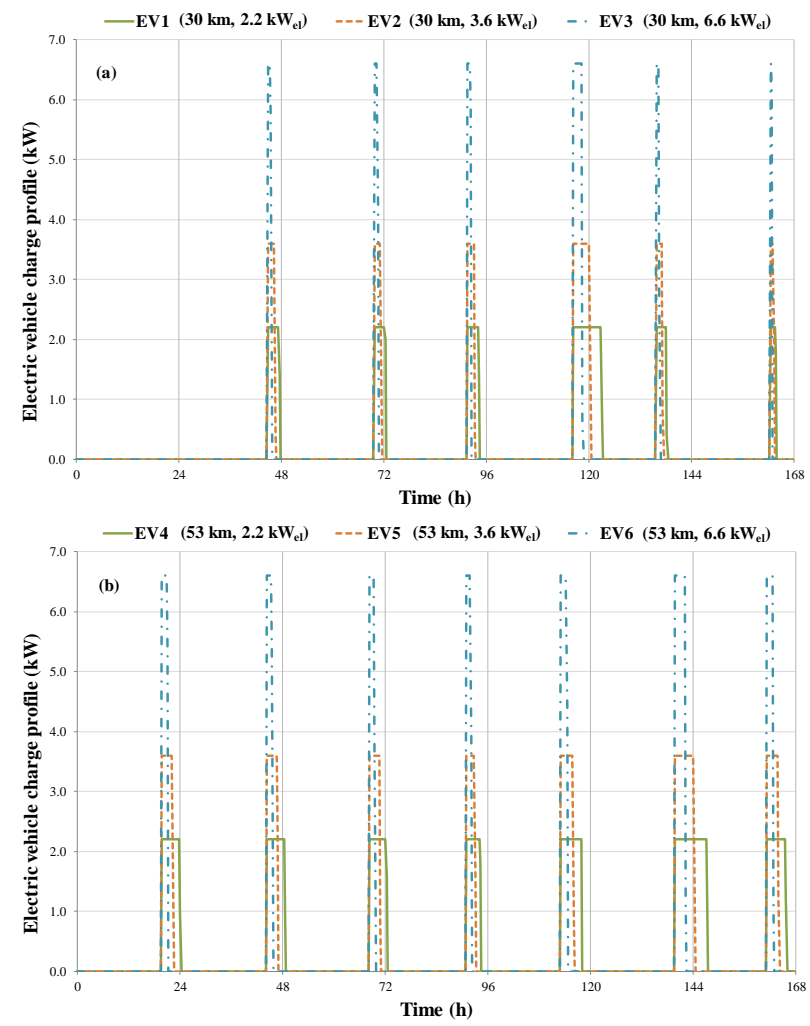

Figure 2: EVs charging profiles with (a) $30 \mathrm{~km}$ as daily driving distance, and (b) $50 \mathrm{~km}$ as daily driving distance.

\section{Simulation models}

The TRaNsient SYStems (TRNSYS) software platform has been used to model and simulate the proposed plant over a 5-year period with a simulation time step of 2 minutes. In this paper the TRNSYS Types have been selected from the TRNSYS libraries and enhanced by manufactures performance data or information available in current scientific literature according to the common characteristics of the components used in practice. The duration of simulation period ( 5 years) has been defined in order to consider that it takes time to fully charge the seasonal storage. January $1^{\text {st }}$ has been assumed as starting date of the simulations.

The Type 56 has been used to model the buildings composing the district. The Type 557a (Hellström, 1989), adopted to model the BTES, is considered to be the stateof-the-art in dynamic simulation of ground heat exchanger that interacts thermally with the ground and has been used by several researchers for simulating energy systems with BTES (Entchev et al., 2018). The storage volume has the shape of cylinder with vertical symmetry axis; within this cylindrical storage volume, the ground is considered to be uniform. There is convective heat transfer in the ducts and conductive heat transfer in the ground. The layout of the borehole field is fixed hexagonally and uniformly within the storage volume in the simulation. The Type 534, used to model the STTES, is based on the assumption that the tank can be divided into fully-mixed equal sub-volumes; in this paper, the STTES has been modelled with 10 isothermal temperature layers to better represent the stratification in the tank, where the top layer is 1 and the bottom layer is 10. The tank model has been calibrated based on manufacturer data (PARADIGMA). Flat-plate solar collectors have been modelled by using the Type $1 \mathrm{~b}$; in this model, the collector efficiency has been defined by a second-order equation and correction for off-normal solar incidence is applied by a second-order incidence angle modifier equation. The coefficients adopted in the equations have been based on manufacturer specifications (KLOBEN). The main boiler has been modelled by the Type 700 by assuming its efficiency depending on the thermal output according to the manufacturer performance data (VAILLANT). Individual boilers installed within the houses for DHW production have been modelled by means of the Type 700 by assuming a constant efficiency of $90 \%$. The performance of the MCHP unit has been defined by means of the Type 907 by assuming a simplified steady-state operation at nominal conditions (thermal output $=28.0 \mathrm{~kW}_{\text {th }}$, electric output $=12.0 \mathrm{~kW}$ el, thermal efficiency $=65.1 \%$, electric efficiency $=27.9 \%$ ). Fan-coils have been modelled by the Type $753 \mathrm{~d}$ and calibrated based on manufacturer data (AERMEC).

In this study, a single pair of supply and return pipes has been used for both the distribution network as well as the solar field collector circuit. The Type 31 has been used to model the pipes and calculate the related heat losses by assuming a loss coefficient equal to $0.05 \mathrm{~kJ} /\left(\mathrm{hm}^{2} \mathrm{~K}\right)$. The DH network pump has been modelled by the Type 742 , while the other pumps in the system have been modelled by means of the Type 656. A specific weather data file (EnergyPlus) has been considered for modelling the climatic conditions of Naples; the weather data are one year long and, therefore, have to be the same each year.

\section{Control logics}

The duration of the heating period has been assumed from $15^{\text {th }}$ November up to $31^{\text {st }}$ March. The DH network pump operates continuously with a flow rate varying between $497.7 \mathrm{~kg} / \mathrm{h}$ and $18,015.7 \mathrm{~kg} / \mathrm{h}$ (depending on the number of buildings requiring thermal energy for space heating) during the heating season. The operation of the HE2 pump depends on the inlet temperature of hot and cold sides ( $\left.T_{\text {in,HE2,hot }}, T_{\text {in,HE2,cold }}\right)$. The heat carrier fluid is a mixture of water and ethylene glycol $(60 \% / 40 \%$ by volume) flowing through the fan-coils only in cases when there is a call for heat triggered by a thermostat installed in each building. The target room temperature $\mathrm{T}_{\text {room,set-point }}$ is 20.0 ${ }^{\circ} \mathrm{C}$ only in the case of at least one occupant being inside the building; when the room temperature $\mathrm{T}_{\text {room }}$ is lower than $19.5^{\circ} \mathrm{C}$ during the heating period, a mass flow rate 
of heat carrier fluid $\dot{\mathrm{m}}_{\mathrm{FC}}$ flows into the fan-coils; the call for heat signal will be disabled when the room temperature reaches $20.5{ }^{\circ} \mathrm{C}$. The set-point for the $\mathrm{DH}$ supply temperature is $55.0^{\circ} \mathrm{C}$, so that the operation of the back-up system (main boiler of MCHP unit) depends on the inlet and outlet temperatures $\left(\mathrm{T}_{\mathrm{in}, \mathrm{MB}} / \mathrm{T}_{\mathrm{in}, \mathrm{MCHP}}\right.$ and $\left.\mathrm{T}_{\text {out,MB }} / \mathrm{T}_{\text {out,MCHP }}\right)$. The target temperature of the DHW mass flow rate $\dot{\mathrm{m}}_{\mathrm{DHW}}$ is assumed equal to $45^{\circ} \mathrm{C}$; the operation of the individual boilers for DHW production depends on their inlet/outlet temperatures $\left(\mathrm{T}_{\mathrm{in}, \mathrm{B}} / \mathrm{T}_{\mathrm{out}, \mathrm{B}}\right)$. The solar energy recover is based on the comparison between the current values of temperature at node 10 (lower part) of STTES T 10 ,STTES and the temperature of the fluid exiting the solar collector field $\mathrm{T}_{\mathrm{SF} \text {,out. The } \mathrm{BTES}}$ charging/discharging is controlled based on the current values of the temperature at nodes 1 (upper part) and 10 (lower part) of STTES ( $T_{1, \text { STTES }}$ and $\mathrm{T}_{10, \mathrm{STTES}}$ ), the temperature in the center of BTES field $\mathrm{T}_{\mathrm{BTES} \text {,center }}$ as well as the room target temperature $\mathrm{T}_{\text {room,set-point. }}$ In more detail, during the BTES charging mode, the flow rate, which is constant, is set to half of the nominal flow rate in the collector array; in the BTES discharging mode, the flow rate is set to the current value used in the distribution network. Table 3 reports the control strategies for the activation/deactivation of the plant components.

\section{Description of the reference system}

A conventional decentralized heating system (CS) has been modeled and simulated to be compared with the proposed CSHPSS while serving the same district with and without the charging of 6 plug-in EVs. In the reference heating system, each building is equipped only with a natural gas-fired boiler (modelled with a constant thermal efficiency of $90.0 \%$ as well as a rated capacity of $26.6 \mathrm{~kW}$ ) for both space heating and DHW production. The heat carrier fluid flows through the radiators installed inside the buildings with the same control logic adopted in the proposed CSHPSS. The set-point of the individual boilers is $55.0^{\circ} \mathrm{C}$ for heating purposes, with a dead band of $5.0{ }^{\circ} \mathrm{C}$ (as in the proposed CSHPSS). The DHW demand profiles used for the proposed CSHPSS have been also assumed for the reference heating system. As in the proposed CSHPSS, the DHW temperature is assumed to be produced at $45^{\circ} \mathrm{C}$.

\section{Methods}

In this paper the simulation results associated to the proposed plant have been compared with those associated to the conventional heating system assumed as reference. The comparison has been performed in terms of primary energy consumption, carbon dioxide equivalent emissions and operating costs as detailed in the next subsections. The energy comparison between the proposed and conventional systems has been performed in terms of primary energy consumption by means of the index named Primary Energy Saving (PES):

$$
\mathrm{PES}=\left(\mathrm{E}_{\mathrm{p}}^{\mathrm{CS}}-\mathrm{E}_{\mathrm{p}}^{\mathrm{CSHPSS}}\right) / \mathrm{E}_{\mathrm{p}}^{\mathrm{CS}}
$$

where $\mathrm{E}_{\mathrm{p}}^{\mathrm{CSHPSS}}$ is the primary energy consumed by the proposed system and $\mathrm{E}_{\mathrm{p}}^{\mathrm{CS}}$ is the primary energy consumed by the conventional system. These terms are calculated as follows:

$$
\begin{gathered}
\mathrm{E}_{\mathrm{p}}^{\mathrm{CSHPSS}}=\mathrm{E}_{\mathrm{th}, \mathrm{MB}} / \eta_{\mathrm{MB}}+\mathrm{E}_{\mathrm{p}, \mathrm{MCHP}}+ \\
+\mathrm{E}_{\mathrm{th}, \mathrm{DHW}} / \eta_{\mathrm{B}}+\mathrm{E}_{\mathrm{el}, \text { import }} / \eta_{\mathrm{PP}} \\
\mathrm{E}_{\mathrm{p}}^{\mathrm{CS}}=\mathrm{E}_{\mathrm{th}, \mathrm{B}} / \eta_{\mathrm{B}}+ \\
+\left(\begin{array}{c}
\mathrm{E}_{\text {el,individual pumps }}+\mathrm{E}_{\text {el, lighting }} \\
+\mathrm{E}_{\text {el, domestic appliances }}+\mathrm{E}_{\mathrm{el}, \mathrm{EV}}
\end{array}\right) / \eta_{\mathrm{PP}}
\end{gathered}
$$

where $E_{\mathrm{th}, \mathrm{MB}}$ is the thermal energy produced by the main boiler, $\mathrm{E}_{\mathrm{p}, \mathrm{MCHP}}$ is the primary energy consumption of the MCHP unit, $E_{t h, D H W}$ is the thermal energy consumed for DHW production in the proposed system, $\mathrm{E}_{\text {el,import }}$ is the electric energy imported/purchased from the grid in the proposed system, $\mathrm{E}_{\mathrm{th}, \mathrm{B}}$ is the thermal energy supplied by the individual boilers for both heating and DHW in the

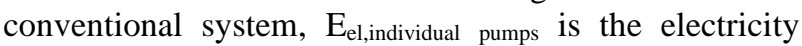
consumed by the individual pumps $\left(\mathrm{P}_{\mathrm{A} 1}, \mathrm{P}_{\mathrm{A} 2}, \mathrm{P}_{\mathrm{B} 1}, \mathrm{P}_{\mathrm{B} 2}, \mathrm{P}_{\mathrm{C} 1}\right.$, $\left.\mathrm{P}_{\mathrm{C} 2}\right), \mathrm{E}_{\text {ell,lighting }}$ is the electric energy consumed by the lighting systems, $\mathrm{E}_{\text {el,domestic appliances }}$ is the electric energy consumed by the domestic appliances and $E_{\mathrm{el}, \mathrm{EV}}$ is the electric energy consumed for the electric vehicles charging, $\eta_{M B}$ is the efficiency of the main boiler, $\eta_{B}$ is the efficiency of the individual boilers, $\eta_{P P}$ is the power plant average efficiency in Italy, including transmission losses, assumed equal to 0.42 (Ciampi et al., 2018). The electric energy imported/purchased from the grid Eel,import is calculated, time-step by time-step, as the difference between the overall electricity demand $E_{\text {el,demand }}$ (due to the pumps, heat dissipator, fan-coils, the lighting systems, domestic appliances as well as electric vehicles charging) and the electric energy congenerated by the MCHP unit $\mathrm{E}_{\mathrm{el}, \mathrm{MCHP}}$ in the case of $\mathrm{E}_{\mathrm{el}, \mathrm{demand}}>\mathrm{E}_{\mathrm{el}, \mathrm{MCHP}}$.

The assessment of the environmental impact has been performed in this study through an energy output-based emission factor approach (Chicco and Mancarella, 2008) in terms of global carbon dioxide equivalent emissions by means of the following indicator:

$$
\Delta \mathrm{CO}_{2}=\left(\mathrm{m}_{\mathrm{CO}_{2}}^{\mathrm{CS}}-\mathrm{m}_{\mathrm{CO}_{2}}^{\mathrm{CSHPSS}}\right) / \mathrm{m}_{\mathrm{CO}_{2}}^{\mathrm{CS}}
$$

where $\mathrm{m}_{\mathrm{CO}_{2}}^{\mathrm{CSHPSS}}$ is the mass of carbon dioxide equivalent emissions associated to the proposed system and $\mathrm{m}_{\mathrm{CO}_{2}}^{\mathrm{CS}}$ is the mass of carbon dioxide equivalent emissions associated to the conventional system. The values of $\mathrm{m}_{\mathrm{CO}_{2}}^{\mathrm{CSHPSS}}$ and $\mathrm{m}_{\mathrm{CO}_{2}}^{\mathrm{CS}}$ used in Eq. 4 have been computed as reported below:

$$
\begin{aligned}
\mathrm{m}_{\mathrm{CO}_{2}}^{\text {CSHPS }} & =\beta \cdot \mathrm{E}_{\mathrm{th}, \mathrm{MB}} / \eta_{\mathrm{MB}}+\beta \cdot \mathrm{E}_{\mathrm{p}, \mathrm{MCHP}} \\
& +\beta \cdot \mathrm{E}_{\mathrm{th}, \mathrm{DHW}} / \eta_{\mathrm{B}}+\alpha \cdot \mathrm{E}_{\mathrm{el}, \text { import }}
\end{aligned}
$$




$$
\begin{aligned}
\mathrm{m}_{\mathrm{CO}_{2}}^{\mathrm{CS}} & =\beta \cdot \mathrm{E}_{\mathrm{th}, \mathrm{B}} / \eta_{\mathrm{B}}+ \\
& +\alpha \cdot\left(\begin{array}{l}
\mathrm{E}_{\text {el,individual pumps }}+\mathrm{E}_{\mathrm{el}, \text { lighting }} \\
+\mathrm{E}_{\mathrm{el}, \text { domestic appliances }}+\mathrm{E}_{\mathrm{el}, \mathrm{EV}}
\end{array}\right)
\end{aligned}
$$

where $\alpha$ is the $\mathrm{CO}_{2}$ equivalent emission factor for electricity production and $\beta$ represents the $\mathrm{CO}_{2}$ equivalent emission factor associated to the natural gas consumption. According to the values suggested by Ciampi et al. (2018) for the Italian scenario, $\alpha$ has been assumed equal to 573 $\mathrm{g}_{\mathrm{CO} 2} / \mathrm{kWh}_{\mathrm{el}}$ and $\beta$ has been considered of $207 \mathrm{~g}_{\mathrm{CO} 2} / \mathrm{kWh}_{\mathrm{p}}$.

\begin{tabular}{|c|c|c|}
\hline & ON & OFF \\
\hline $\begin{array}{c}\text { Individual pumps } \\
\& \text { FC blower }\end{array}$ & $\begin{array}{l}\text { Heating period AND } \\
\mathrm{T}_{\text {room }} \leq 19.5^{\circ} \mathrm{C}\end{array}$ & $\begin{array}{c}\text { Cooling period OR } \\
\mathrm{T}_{\text {room }} \geq 20.5^{\circ} \mathrm{C}\end{array}$ \\
\hline $\begin{array}{l}\text { Solar pump \& } \\
\text { HE1 pump }\end{array}$ & $\begin{array}{c}\left(\mathrm{T}_{\mathrm{SF}, \text { out }}-\mathrm{T}_{10, \mathrm{STTES}}\right) \geq \\
10^{\circ} \mathrm{C} \text { AND } \\
\mathrm{T}_{1, \mathrm{STTES}} \leq 90^{\circ} \mathrm{C}\end{array}$ & $\begin{array}{c}\left(\mathrm{T}_{\mathrm{SF}, \text { out }}-\mathrm{T}_{10, \mathrm{STTES}}\right) \leq \\
2^{\circ} \mathrm{C} \text { OR } \\
\mathrm{T}_{1, \mathrm{STTES}}>90{ }^{\circ} \mathrm{C}\end{array}$ \\
\hline $\begin{array}{l}\text { BTES pumps } \\
\text { (charging and } \\
\text { discharging) }\end{array}$ & 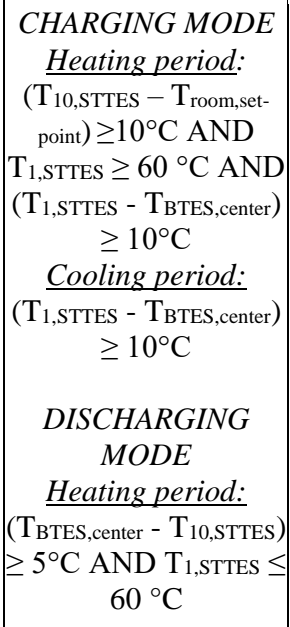 & 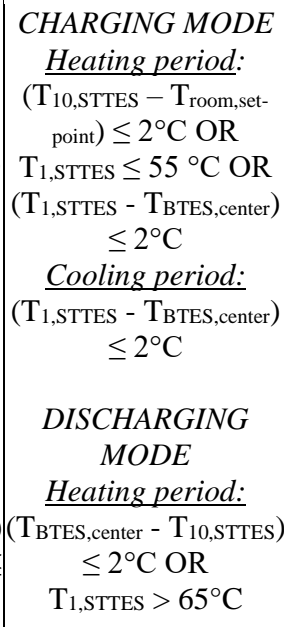 \\
\hline $\begin{array}{l}\text { DH network } \\
\text { pump }\end{array}$ & $\begin{array}{l}\text { Heating period AND } \\
T_{\text {room }} \leq 19.5^{\circ} \mathrm{C}\end{array}$ & $\begin{array}{c}\text { Cooling period OR } \\
\text { (Heating period AND } \\
\left.\mathrm{T}_{\text {room }} \geq 20.5^{\circ} \mathrm{C}\right)\end{array}$ \\
\hline HE2 pump & $\begin{array}{l}\text { DH network pump } \\
\text { ON AND } \\
\left(\mathrm{T}_{\text {in,HE2,hot }-}\right. \\
\mathrm{T}_{\text {in,HE2,cold })} \geq 5^{\circ} \mathrm{C}\end{array}$ & $\begin{array}{c}\text { DH network pump } \\
\text { OFF OR } \\
\left(\mathrm{T}_{\text {in,HE2,hot }-}\right. \\
\mathrm{T}_{\text {in,HE2,cold }) \leq 2{ }^{\circ} \mathrm{C}}\end{array}$ \\
\hline$\frac{\text { Main }}{\text { boiler/MCHP unit }}$ & $\begin{array}{l}\text { Heating period AND } \\
\dot{\mathrm{m}}_{\mathrm{FC}} \neq 0 \text { AND } \\
\mathrm{T}_{\mathrm{in}, \mathrm{MB}} / \mathrm{T}_{\mathrm{in}, \mathrm{MCHP}}<50^{\circ} \mathrm{C}\end{array}$ & $\begin{array}{c}\text { Coiling period OR } \\
\dot{\mathrm{m}}_{\mathrm{FC}}=0 \mathrm{OR} \\
\mathrm{T}_{\mathrm{out}, \mathrm{MB}} / \mathrm{T}_{\mathrm{out}, \mathrm{MCHP}} \geq \\
55^{\circ} \mathrm{C}\end{array}$ \\
\hline \begin{tabular}{|c|} 
Individual boilers \\
for DHW \\
production
\end{tabular} & $\begin{array}{c}\dot{\mathrm{m}}_{\mathrm{DHW}} \neq 0 \text { AND } \\
\mathrm{T}_{\mathrm{in}, \mathrm{B}}<45^{\circ} \mathrm{C}\end{array}$ & $\begin{aligned} \dot{\mathrm{m}}_{\mathrm{DHW}} & =0 \text { AND } \\
\mathrm{T}_{\mathrm{in}, \mathrm{B}} & \geq 45^{\circ} \mathrm{C}\end{aligned}$ \\
\hline
\end{tabular}

Table 3: Control strategies of proposed CSHPSS.

The economic analysis has been performed by comparing the operating costs of the proposed system with those of the reference heating system by means of the following parameter:

$$
\Delta \mathrm{OC}=\left(\mathrm{OC}^{\mathrm{CS}}-\mathrm{OC}^{\mathrm{CSHPSS}}\right) / \mathrm{OC}^{\mathrm{CS}}
$$

where OC ${ }^{\text {CSHPSS }}$ represents the operating costs associated to the proposed system and $\mathrm{OC}^{\mathrm{CS}}$ represents the operating costs associated to the conventional system. The values of ${ }^{\circ C}{ }^{C S}$ and ${ }^{C C}{ }^{C S H P S S}$ used in Eq. 7 have been computed as reported below:

$$
\begin{aligned}
\mathrm{OC}^{\mathrm{CSHPSS}}= & \mathrm{UC}_{\mathrm{ng}} \cdot \mathrm{E}_{\mathrm{th}, \mathrm{MB}} /\left(\mathrm{LHV}_{\mathrm{ng}} \cdot \rho_{\mathrm{ng}} \cdot \eta_{\mathrm{MB}}\right)+ \\
& +\mathrm{UC}_{\mathrm{ng}, \mathrm{MCHP}} \cdot \mathrm{E}_{\mathrm{p}, \mathrm{MCHP}} /\left(\mathrm{LHV}_{\mathrm{ng}} \cdot \rho_{\mathrm{ng}}\right)+ \\
& +\mathrm{UC}_{\mathrm{ng}} \cdot \mathrm{E}_{\mathrm{th}, \mathrm{DHW}} /\left(\mathrm{LHV}_{\mathrm{ng}} \cdot \rho_{\mathrm{ng}} \cdot \eta_{\mathrm{B}}\right)+ \\
& +\mathrm{UC}_{\mathrm{el}} \cdot \mathrm{E}_{\mathrm{el}, \text { import }}-\mathrm{UC}_{\mathrm{el}, \text { sold }} \cdot \mathrm{E}_{\mathrm{el}, \mathrm{MCHP}, \text { exp }} \\
\mathrm{OC}^{\mathrm{CS}}= & \mathrm{UC}_{\mathrm{ng}} \cdot \mathrm{E}_{\mathrm{th}, \mathrm{B}} /\left(\mathrm{LHV}_{\mathrm{ng}} \cdot \rho_{\mathrm{ng}} \cdot \eta_{\mathrm{B}}\right)+ \\
+ & \mathrm{UC}_{\mathrm{el}} \cdot\left(\begin{array}{l}
\mathrm{E}_{\mathrm{el}, \text { individual pumps }}+ \\
\mathrm{E}_{\mathrm{el}, \text { lighting }}+ \\
\mathrm{E}_{\mathrm{el}, \text { domestic appliances }}+\mathrm{E}_{\mathrm{el}, \mathrm{EV}}
\end{array}\right)
\end{aligned}
$$

where $\mathrm{UC}_{\mathrm{ng}}$ is the unit cost of natural gas consumed by the boilers (ARERA), $\mathrm{UC}_{\mathrm{ng}, \mathrm{MCHP}}$ is the unit cost of natural gas consumed by the MCHP unit (ARERA), $\mathrm{LHV}_{\mathrm{ng}}$ is the lower heating value of natural gas (assumed equal to $49,599 \mathrm{~kJ} / \mathrm{kg}$ ) and $\rho_{\mathrm{ng}}$ is the density of natural gas (assumed equal to $0.72 \mathrm{~kg} / \mathrm{m}^{3}$ ) (Ciampi et al., 2018), $\mathrm{UC}_{\mathrm{el}}$ is the unit cost of electric energy purchased from the central grid (ARERA), $\mathrm{UC}_{\mathrm{el}, \mathrm{sold}}$ is the unit cost of the cogenerated electricity exported to the grid ( $\left.\mathrm{E}_{\mathrm{el}, \mathrm{MCHP}, \exp }\right)$ (GSE). The tariffs of both the electric energy as well as the natural gas have been kept up-to-date according to the Italian scenario (ARERA, GSE).

\section{Results}

The following 4 plant configurations have been simulated and analyzed over a period of 5 years:

1) Boiler w/o EVs: CSHPSS equipped with the main boiler as back-up system, without considering the charging of $6 \mathrm{EVs}$;

2) Boiler with EVs: CSHPSS equipped with the main boiler as back-up system, in the case of the $6 \mathrm{EVs}$ have to be charged;

3) MCHP w/o EVs: CSHPSS equipped with the MCHP unit as back-up system, without considering the charging of 6 EVs;

4) Boiler with EVs: CSHPSS equipped with the MCHP unit as back-up system, in the case of the $6 \mathrm{EVs}$ have to be charged.

Figure 3 reports the values of PES as a function of the simulation year for the above-mentioned 4 configurations. This figure highlights that the values of PES significantly increase from the $1^{\text {st }}$ to the $2^{\text {nd }}$ year of operation and then become substantially constant; this is thanks to the fact that the average temperature of the long-term thermal energy storage mainly increases from the $1^{\text {st }}$ to the $2^{\text {nd }}$ year of simulation, allowing for a more effective exploitation of solar energy. Similar trends have been obtained for the values of $\Delta \mathrm{CO}_{2}$ and $\triangle \mathrm{OC}$, so that the performance during 
the $5^{\text {th }}$ year of operation can be assumed as the steadystate value (whatever the plant configuration is).

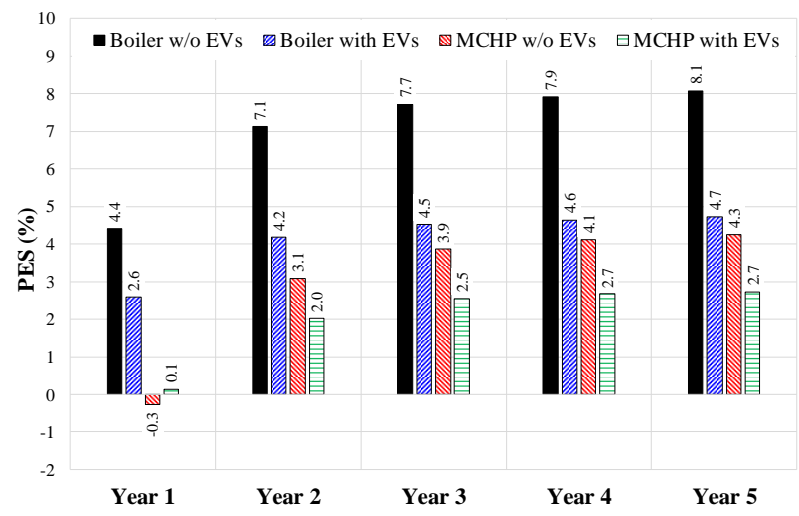

Figure 3: Values of PES as a function of the time.

Figure $4 \mathrm{a}$ reports the values of PES, $\Delta \mathrm{CO}_{2}$ and $\triangle \mathrm{OC}$, while figure $4 \mathrm{~b}$ highlights the main energy flows during the $5^{\text {th }}$ year of simulation upon varying the configuration plant; in particular, the electric energy generated by the MCHP unit, the electric energy imported from the grid, the electric energy exported to the grid, the net solar energy recovered from solar collectors, the thermal energy injected into the BTES, the thermal energy extracted from the BTES, the thermal energy supplied by the main boiler or the MCHP unit are indicated in Figure $4 b$.

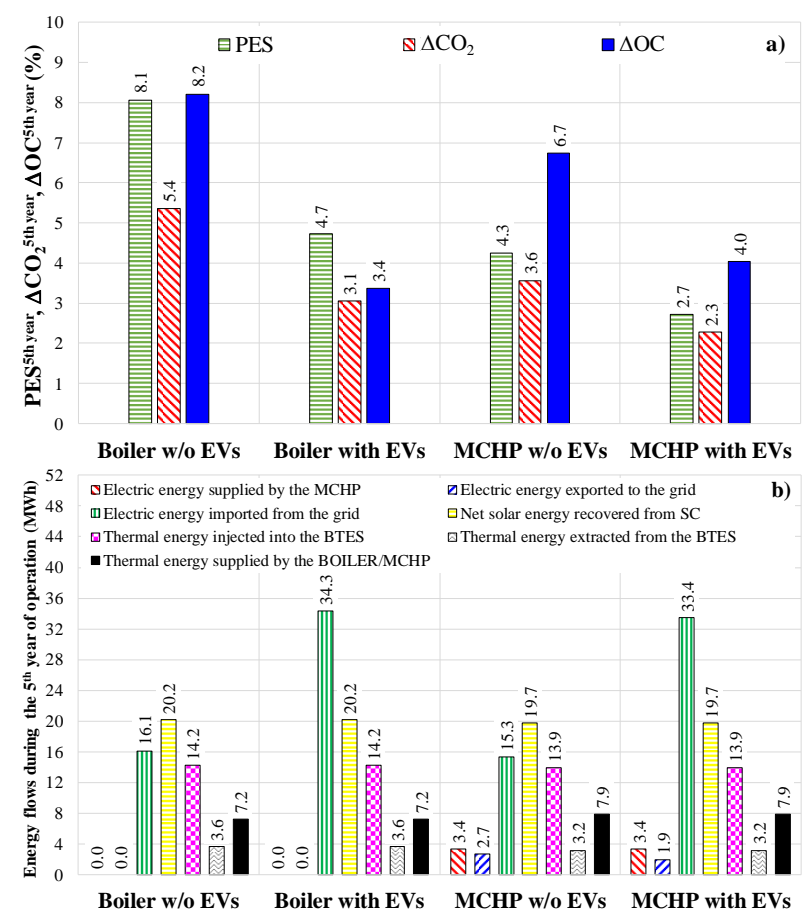

Figure 4: (a) PES, $\triangle \mathrm{CO}_{2}, \triangle O C$, and (b) energy flows during the $5^{\text {th }}$ year of simulation.

Figures $4 \mathrm{a}$ and $4 \mathrm{~b}$ show that:

- the values of PES ${ }^{5 \text { th year }}, \Delta \mathrm{CO}_{2}{ }^{\text {th year }}$ and $\Delta \mathrm{OC}^{5 \text { th year }}$ are always positive, whatever the configuration plant is; this means that the proposed configurations of the CSHPSS allow to reduce the primary energy consumption, the equivalent $\mathrm{CO}_{2}$ emissions and the operating costs in comparison to the reference heating system at any case;

- the maximum values of $\operatorname{PES}^{5 \text { th year }}(8.1 \%), \Delta \mathrm{CO}_{2}{ }^{5 \text { th year }}$ $(5.4 \%)$ and $\Delta O C^{\text {th year }}(8.2 \%)$ are obtained in the case of the main boiler is used as back-up system, without considering the EVs charging;

- the worst energy, environmental and economic performance $\left(\mathrm{PES}^{5 \text { th year }}=2.7 \%, \Delta \mathrm{CO}_{2}{ }^{\text {th year }}=2.3 \%\right.$ and $\Delta \mathrm{OC}^{5 \text { th }}$ year $\left.=4.0 \%\right)$ corresponds to the configuration including the MCHP unit as back-up system together with the EVs charging;

- whatever the back-up system (main boiler or MCHP unit) is, the EVs charging significantly reduces the values of $\mathrm{PES}^{5 \text { th year }}, \Delta \mathrm{CO}_{2}{ }^{5 \text { th year }}$ and $\Delta \mathrm{OC}^{\text {th year }}$ in comparison to the case when the EVs charging is not taken into account; this is due to the fact that the amount of electric energy imported from the grid increases with the utilization of the EVs. The reduction is more relevant when the boiler is adopted as back-up system (with the values of $\mathrm{PES}^{5 \text { th year, }}$ $\Delta \mathrm{CO}_{2}{ }^{\text {th year }}$ and $\Delta \mathrm{OC}^{\text {th year }}$ lowered by about $3.4 \%$, $2.3 \%$ and $4.8 \%$, respectively) due to the fact that in this case the total electric demand is fully covered by the central grid (without the contribution of cogenerated electricity);

- in the case of the EVs have to be charged, the best energy and environmental performance $\left(\mathrm{PES}^{5 \text { th }}\right.$ year $=4.7 \%, \Delta \mathrm{CO}_{2}{ }^{\text {th year }}=3.1 \%$ ) are obtained when the boiler is used as back-up system thanks to the fact that the solar energy recovered from solar collectors is more significant, allowing for a lower thermal contribution from the back-up system (even if the electricity imported from the grid is larger), while the adoption of the MCHP unit allows to achieve a larger saving in terms of operating costs $\left(\Delta \mathrm{OC}^{5 \text { th year }}=4.0 \%\right)$ thanks to (i) the lower unit cost of natural gas for cogenerative use with respect to other applications, (ii) the revenues associated to the electric energy (about 1.9 MWh) sold to the grid, and (iii) the reduced electricity imported from the grid.

\section{Conclusions}

The energy, environmental and economic performance of a solar hybrid district heating network integrated with a seasonal borehole thermal energy storage are analyzed and compared with those of a conventional heating system upon varying the back-up system as well as the electric demand profiles (with or without 6 electric vehicles). The results highlighted that: (i) the proposed configurations of the CSHPSS allow to reduce the primary energy consumption, the equivalent $\mathrm{CO}_{2}$ emissions and the operating costs in comparison to the reference heating system at any case; (ii) whatever the back-up system (boiler or MCHP unit) is, the EVs charging significantly reduces the overall performance; (iii) if the EVs charging is not performed, the configuration with the boiler as back-up system allows to obtain better results with respect to the case with the MCHP unit. 


\section{References}

AERMEC, global.aermec.com/en/products/productsheet/?t=Hydronic $\% 20$ terminal\%20units\&c=CAT_5 0HZ_UE\&f=terminal $\&$ Code $=\mathrm{UL}$.

Angrisani G., Canelli M., Roselli C., Sasso M. (2015). Integration between electric vehicle charging and micro-cogeneration system. Energy Convers Manage 98, 115-26.

Angrisani, G., Rosato, A., Roselli C., Sasso M., Sibilio S., Unich A. (2014). Influence of climatic conditions and control logic on $\mathrm{NO}_{\mathrm{x}}$ and $\mathrm{CO}$ emissions of a microcogeneration unit serving an Italian residential building. Appl Therm Eng 71(2), 858-71.

ARERA, Italian Regulatory Authority for Energy, Networks and Environment, www.arera.it/it/inglese/index.htm.

Buoro, D., Pinamonti, P., Rein, M. (2014). Optimization of a Distributed Cogeneration System with solar district heating. Applied Energy 124, 298-308.

Chicco, G., Mancarella, P. (2008). Assessment of the greenhouse gas emissions from cogeneration and trigeneration systems. Part I: models and indicators. Energy 33(3), 410-417.

Ciampi, G, Rosato, A, Sergio, S. (2018). Thermoeconomic sensitivity analysis by dynamic simulations of a small Italian solar district heating system with a seasonal borehole thermal energy storage. Energy $143,757-771$

\section{COGENGREEN.}

www.cogengreen.com/sites/default/files/fichiers_gn/ en_technspec-12ag-cogengreen-20141229.pdf.

Directive 2012/27/EU. OJ L315, 14 November 2012.

EnergyPlus. Weather data https://energyplus.net/weather-

location/europe_wmo_region_6/ITA//ITA_Naples.16 2890 IWEC.

Entchev, E., Yang, L., Ghorab, M., Rosato, A., Sibilio, S. (2018). Energy, economic and environmental performance simulation of a hybrid renewable microgeneration system with neural network predictive control. Alexandria Engineering Journal, $57,455-473$

GSE,gse.it/servizi-per-te/fotovoltaico/scambio-sul-posto.

Jordan U., Vajen K. (2001). Realistic Domestic HotWater Profiles in Different Time Scales. http://sel.me.wisc.edu/trnsys/trnlib/iea-shctask26/iea-shc-task26-load-profiles-descriptionjordan.pdf.

Hellström G. (1989). Heat Storage in the Ground, Duct ground heat storage model, Manual for Computer Code. Department of Mathematical Physics, University of Lund, Box 118, S-221 00 Lund, Sweden.

Kallert, A., Schmidt, D., Bläse, T. (2017). Exergy-based analysis of renewable multi-generation units for small scale low temperature district heating supply. Energy Procedia 116, 13-25.

KLOBEN, www.kloben.it/products/view/3.

Italian Ministerial Decree DM 26/06/2015. www.gazzettaufficiale.it/do/atto/serie_generale/caric aPdf?cdimg=15A0519800100010110002\&dgu=2015 -07-15\&art.dataPubblicazioneGazzetta=2015-07$15 \&$ art. codiceRedazionale $=15$ A $05198 \&$ art. num $=1 \&$ art.tiposerie $=$ SG

Marguerite, C., Schmidt, R.R., Pardo-Garcia, N., Abdurafikov, R. (2017). Simulation based multicriteria evaluation of design scenarios for an industrial waste heat based micro district heating network supplying standard and low-energy buildings. Energy Procedia 116, 128-137.

Mura P.G., Baccoli R., Innamorati R., Mariotti S. (2015). An energy autonomous house equipped with a solar PV hydrogen conversion system. Energy Procedia 78, 1998-2003

Mura P.G., Baccoli R., Innamorati R., Mariotti S. (2015). Solar energy system in a small town constituted of a network of photovoltaic collectors to produce electricity for homes and hydrogen for transport services of municipality. Energy Procedia 78, 824829.

Natural Resources Canada. The Plug-in Electric Vehicle - Charge Impact Model (PEV-CIM), www.nrcan.gc.ca/energy/software-tools/7441.

PARADIGMA, www.paradigmaitalia.it/serbatoioaccumulo-acqua-calda-riscaldamento/boileraccumulo-acqua-calda/accumulo-solare-termico.

Rad, F. M., Fung, A. S. (2016). Solar community heating and cooling system with borehole thermal energy storage - Review of systems. Renewable Sustainable Energy Reviews 60, 1550-1561.

Ribberink H., Entchev E. (2014). Exploring the potential synergy between micro-cogeneration and electric vehicle charging. Appl Therm Eng 71, 677-685.

Richardson I., Thomson M., Infield D., Clifford C. (2010). Domestic electricity use: a high-resolution energy demand model. Energy and Buildings 42, 1878-1887.

Rosato, A., Sibilio, S., Angrisani, G., Canelli, M., Roselli, C., Sasso, M., Tariello, F. (2017). The microcogeneration and emission control and related utilization field. Lecture Notes in Energy 33, 795-834.

Sibilio, S., Rosato A. (2015). Energy technologies for building supply systems: MCHP. In Boemi S.-N., Irulegi O., Santamouris M. Energy Performance of Buildings. Springer International Publishing. Switzerland.

TRNSYS. www.trnsys.com.

VAILLANT. Www.vaillant.it/home/prodotti/atmotecexclusive-vmw-9664.html. 